\title{
Anxious urbanity: xenophobia, the native subject and the refugee camp
}

\section{Suren Pillay}

\begin{abstract}
Could we think of the black subject under apartheid as a refugee, and might this condition be the paradigmatic metaphor for thinking about the postcolonial African predicament of citizenship? This paper considers the xenophobic violence that occurred in South Africa in 2008 and recasts that event by thinking about the plight of the refugee as part of what it argues is a genealogy of "anxious urbanity." This, the paper suggests, has defined the urban subject of colonial and apartheid modes of governmentality and has consequences for how we think about the postcolonial present of citizenship.
\end{abstract}

\section{Anx-ious}

Adj.: Uneasy and apprehensive about an uncertain event or matter ${ }^{1}$

How do we think about the xenophobic violence we have seen in South Africa, most pronounced in May of 2008? A violence made scandalous by the photograph of the killing and setting alight of a Mozambican migrant worker, Ernesto Nhamuave - a story that ran on the front pages of almost every newspaper in South Africa? And a violence that produced a public human rights-based campaign amongst "civil society," and also produced the rows and rows of white tents that we know as the refugee camp, and which the South African government was quick to want to dismantle? This paper is an attempt to offer a way to think about how pain and suffering invokes a certain kind of political subject, which might be seen as the paradigmatic metaphor for a postcolonial African predicament. I explore this predicament by tracing the colonial lineages of what I am calling an "anxious urbanity," specifically for African populations in South Africa, under apartheid, in order to illuminate the contemporary predicament of decolonising citizenship.

When the picture of the killing of Ernesto Nhamuave ran on a Monday morning in the daily papers, the caption and the accompanying story were silent on what happened after. A reporter recalled a panicked resident warning police that "Shangaans are being attacked." We were told that "one plump woman [...] could not contain her laughter [...] and regaled her audience with details of the event" ("Rampaging Mobs Attack Foreigners," Cape Times, May 12, 2008). This reaction to the photograph, which 
brought laughter to some and horror to others, marked a disjuncture in how we imagined the post-apartheid nation and ruptured certain conceptions of it.

The picture caused what we might describe as a scandal. Its scandal was out in the open for all to see: refugees, the most vulnerable people on this continent, were being attacked and killed by the poor of South Africa's townships, who too are counted as amongst the most vulnerable on this continent. South African exceptionalism was further erased in this moment of becoming post-apartheid. Modern economies, globalisation and colonial empires have moved goods, capital and people for centuries, giving rise to tensions and animosities. More presciently, throughout colonised Africa, indigeneity had become a politicised matter (Mamdani 2002a). The colonial state distributed rewards and punishment through braiding rights, space and place into the foundations of colonial governmentality as indirect rule in Africa. This had the effect of turning origins, of where you came from, into a continuing political question.

In his reflections on violence after colonial rule, written in 1963, Frantz Fanon observed with a foreboding clarity: "The colonized man will first manifest this aggressiveness which has been deposited in his bones against his own people [...] the colonized man is an envious man" (Fanon 1963, 40). Without a meaningful decolonisation of the society which benefits all, Fanon warned, this envy in the post-independence period turns on outsiders: "From nationalism, we have passed to chauvinism, and finally to racism. These foreigners are called on to leave, their shops are burned, their street stalls wrecked [...] We observe a permanent seesaw between African unity, which fades quicker and quicker into the mists of oblivion" (41).

When the violence of 2008 broke out, I was part of a research team hastily assembled to look into the matter (Human Sciences Research Council of South Africa 2008). ${ }^{2}$ The dominant discourse through which the plight of the victims was articulated in what is called "civil society" in South Africa - the NGO sector in particular - was through a recourse to various international conventions on human rights which foregrounded the subject as a victim and the problem as suffering. This is, we might say, the hegemonic discourse through which pain and suffering is mediated in our post-Cold War political present. I am using suffering here to describe the way in which an experience of a wrong is mediated through a discourse that lodges it in the abstraction of an individuated body. When "natural rights" becomes secularised as "human rights," the violation of bodily integrity is considered a human rights violation. This, as Samuel Moyn has argued (2010, 7), has become the hegemonic discourse through which to name a wrong in the contemporary world:

The ideological ascendancy of human rights in living memory came out of a combination of separate histories that interacted in an unforeseeable explosion. Accident played a role, as it does in all human events, but what mattered most of all was the collapse of prior universalistic schemes, and the construction of human rights as a persuasive alternative to them.

When the residents of informal settlements expelled foreign nationals from these areas, attacked them and looted stores, a new urban refugee was produced. New 
because the urban refugee of apartheid - the anxious urban subject, a subject rendered migrant or illegal - is the anticipation of this subject position. Now, betwixt and between, the United Nations intervened, along with the South African government, to set up refugee camps. The South African government adopted a policy designed to prevent the existence of any enduring formally constituted refugee camp. It decreed that those in the temporary refugee camps be "reintegrated" to the informal settlements they had fled from. Those who resisted reintegration would face deportation. Reintegration was not thought of as an organised or institutionalised process, but simply as an injunction to return. Mindful of the status of the camp as a site of care, and the possible quandary of the consequences of creating permanent temporary camps, the South African government was in haste to dismantle urban camps before its occupants might make claims to be citizens who seek both representation and care. It was already having enough of a problem with controversy around its existing facility for administering undocumented migrants, the Lindela Repatriation Centre. 3 After some protest by NGOs, these temporary camps were allowed to endure slightly longer than the two-month period decreed; and a year later, in May 2009, the provincial government of the Western Cape applied for the eviction of 461 refugees in two camps in the province. 4

What might be at stake here in this anxiety - if we think of this violence not singularly from the vantage point of the economic, nor from the vantage point of the victim of human rights, but from the vantage point of colonial governmentality - is the incomplete decolonisation that Fanon had signalled. To consider this, I will revisit the politics of pain, suffering and belonging in apartheid South Africa in order to grasp the politics of refuge in relation to citizenship, forced removals and the law. Rather than focus on the exceptional violence of apartheid, my concern is to consider the relationship between a present violence against foreigners and the violence inherent in the legal foundations of apartheid. It is here that we find the will to administer groups by recasting their legal status, and to recast that status in relation to who would have the right to citizenship and who would be an anxious urban or migrant dweller.

If the military camp of national liberation produces the "cadre," or for the settler colonial state the "terrorist," the apartheid township produced the reluctant rural subject resistant to becoming a Bantustan foreigner. The refugee camp produces another kind of subject: the victim, a target that should not be made to die, but the subject that must be made to live. In other words, the object of care. The camp, like the townships in this sense is a site of biopolitical displacement, and the site of pain and suffering. It is here that the question of the political subject, and the right of the political subject to have rights, or to be a refugee who is represented by others, becomes apparent.

The German political theorist Hannah Arendt drew our attention a long while ago to the "perplexities" of human rights, when she observed that the recourse to human rights, which transcended membership of a national political community, could only be accessed through membership of that community in the first instance. In other words, one had to have the right to have human rights, a right that could only be granted and enforced through a nation-state. Arendt also argued that the appeal to human rights 
resonated uncannily with an appeal for the rights of animals, rendering the human without speech (Arendt 1973, 278):

No paradox of contemporary politics is filled with a more poignant irony than the discrepancy between the efforts of well-meaning idealists who stubbornly insist on regarding as 'inalienable' those human rights which are enjoyed only by citizens of the most prosperous and civilized countries, and the situation of the rightless themselves.

There is a disjuncture between what Arendt gestures to as the "rightless themselves" and those most prosperous. But let us adapt Arendt to speak to an African condition - to say that we are not talking about the "rightless" in this instance, but to different ways in which rights are being engaged, claimed and protected. And that rather than between a first world and a third world, or a coloniser and colonised, or developed and underdeveloped as discrete entities, we are talking about geographically proximate but economically, socially and culturally distinct communities of apartheid within the same state. In this Manichean world, some are asserting and claiming their rights themselves. And some are asserting and claiming rights on behalf of others, mediating between these worlds. There is therefore, with repetition and difference, what we might call the desire to judicialise political discontent. That is to say, constitutionalism corrals politics and its forms of discontent into legal-juridical channels and discourses. If the anxious urban subject of apartheid had its advocates to campaign on their behalf, then the anxious urban subject of post-apartheid finds its mediator in the advocacy of NGOs. In historical context, these are significant political practices, which are not to be undervalued in any way. However, they do put into play effects that have important implications for how democracy is lived, particularly where the desire and the practice exist in the space of a normalised disjuncture that characterises most of the postcolonial world (Chatterjee 2006).

The French philosopher Jacques Rancière (2004) has more recently suggested that Arendt's critique of human rights "depoliticizes" human rights. Rancière offers instead a more tactile configuration that opens up the spaces for a politics, of what he calls "dissensus," produced through a process of political subjectivisation. Mindful of this critique, it remains however worth thinking about these instances of violence in relation to a legacy of rights on this continent. Let us recall that for the political subject of colonial modernity, rights belonged to non-natives, not natives. And non-natives were races. 5

In the following section of the paper, I describe an autobiographical narrative of law in relation to apartheid violence. I do so in order to draw attention to an account of law that renders apartheid as its exceptional violence rather than as an everyday legality, an everyday legality that also happened to be declared a crime against humanity. My main concern here is to draw attention to the most pernicious element of apartheid, which was also the feature that made apartheid "a generic form of the colonial state": its desire to denationalise the majority of the population, resulting in the consequence of millions of mass forced removals of subject African populations from urban areas. This was the desire to resolve the native question by rendering the majority both foreign and migrant. It characterises urbanity of African populations in South Africa as a condition 
of anxiety, an unsettled malady of being on the cusp of criminality. It is in this logic, I suggest, that a number of lineages are put into play in the field of political identity through which the xenophobic violence of 2008 should be approached.

\section{Apartheid's refugees}

The declaration of apartheid as a crime against humanity in 1965 described four key features that rendered apartheid such a crime: firstly, by denationalising the majority, making them foreigners and migrants; secondly, by denying the majority political participation; thirdly, by denying the majority self-determination; and lastly, by transacting the previous three elements through brute and systematic use of force. In other words, the resolution emphasised sovereignty and its denial. Its focus was on the colonial features of apartheid. Force itself was considered as the consequence of the latter. It was an effect of the attempt to implement colonial policies. In contrast to this view, a particular kind of critique of apartheid evolves to take a different view on the wrong of apartheid. It takes "racial discrimination" rather than self-determination and the right to sovereignty as its key focus. And it comes to focus on force - its victims and its perpetrators - as the most visible wrong of apartheid.

This critique of apartheid I describe as a human rights-derived critique, and it is the hegemony of this critique during the latter years of the anti-apartheid struggle that, I would contend, comes to frame the way in which the Truth and Reconciliation Commission (TRC) comes to interpret its mandate. The result is, as Mahmood Mamdani (2002c) has argued, is we have come to a conclusion that there were 22,000 victims of gross violations of human rights committed under apartheid, a rather small number in proportion to the millions who were victims of the colonial features of apartheid, the features that targeted collective identities, through race and ethnicity, rather than individual victims of exceptional violence. It is often over-looked that the Population Registration Act of 1950 did not just divide South Africa into the taxonomic categories of race; it divided the population by ethnicity, too. ${ }^{6}$ Black South Africans were to be ethnic subjects, while the rest would be racially classified. Ethnic groups lived under customary law, and races lived under civil law. Races had access to rights in the civil realm of civil society. Subjects, in the most ambitious dreams of apartheid's proponents, would not be South African citizens, but rather belong politically to the homelands and therefore would not have access to civic rights. They could live in white South Africa, but they could not belong there nor have rights there. In his 1964 book on the Pondoland Revolt, Govan Mbeki, the Eastern Cape intellectual, political prisoner and senior ANC leader, set out the challenge for the South African state with remarkable lucidity (Mbeki [1964] 1984, 37-38):

The problem was plain - apartheid had to find a new way to administer Africans, because the pressure for more rights was growing too strong a challenge. [...] The traditional system in South Africa had been one of direct rule: White government officials sat over Chiefs. Everyone knew that the Commissioner was the boss. Yet now the White government official has become too visible and accessible a target for antigovernment action. The need was clearly to devise a system under which the Africans appeared to be managing their own affairs. This, too, of course, was nothing new. 
Indirect rule had been carefully evolved by Lord Lugard for the British colonies in Africa; Nigeria and the former Gold Coast had been governed this way.

Delivering the first Ernie Wentzel Memorial Lecture (1987),7 the senior South African advocate, Sydney Kentridge QC, dwelt at length in the opening of his talk on the ethics and ideological beliefs that the late Ernie Wentzel had come to stand for. Wentzel, he noted, "held strong beliefs about the law and about the society in which he practiced law. [...] He detested racism, white or black, and he detested Fascism, whether of the left or the right. Above all," noted Kentridge, "he believed in individual rights and individual choices." Holding these beliefs, recalled Kentridge, would mean that it was "inevitable" that Wentzel would become an the government, and "inevitable too, that in his profession he should the government, and "inevitable too, that in his profession he should be a forceful defender of the victims of government policies" (1987, 11). This inevitable conflict and oppositional stance would lead to a threemonth spell of detention without trial for the advocate who opposed the laws of the government during the 1960 State of Emergency.

In this recounting of the life of Ernie Wentzel, a life held up as exemplary for its principled, unwavering and courageous defence of the law, Kentridge, who viewed himself no doubt as sympathetic and following in the vein of Wentzel's example of what law should do and be, was upholding a certain normative conception of what it meant to be a lawyer. This was a question of deep deliberation amongst a minority of lawyers and judges in South Africa, articulated as: what would their "role" be in such a context? (Steytler 1987; Adam 1988; Friederichs 1990; Wacks 1984). As we saw, Wentzel was lauded for not being an "ideological figure"; he eschewed the political, whether of the right or the left. His vision of the law is neither of place nor time, neither partisan nor parochial, but is presented as universal, underpinned by the dictum of neither fear nor favour, committed only to itself and the imperatives imminent to this. Of course, Wentzel and Kentridge were drawing on a particular sensibility here that is central to our understanding of the modern state that derives from an understanding of law as, in its Kantian formulation, "the highest form of reason." It is also an understanding of law as a civilisational marker that embodies within it rights that derive from a distinct but dialogical relationship between "natural rights," and "positive law," upon which social contract theory as the foundational "myth" of the modern state rests. This is most starkly exemplified in key texts of Enlightenment thinkers like Thomas Hobbes's Leviathan ([1651] 1985), and John Locke's Two Treatise of Government ([1689] 1993) as rationales for the emergence of the modern regime of sovereign law. ${ }^{8}$ It is the writings of the latter, in particular, that have come to be seen as canonical to the foundations of liberalism.

This account of law and the modern state takes the autobiography of an evolutionary narrative at its face value and brackets, to the extent that it is possible, the entanglements and complicated relationship between liberalism, colonialism and empire. What is crucial though is that the tension between the universal claims of liberalism and its particular, and now well-documented, categorical exclusions, are central to the anxiety that motivates the human rights lawyers, particularly in the South African iteration of modernity. In a different context, Uday Singh Mehta (1999) has argued 
for a distinction between a notion of empire and colony that is worth bearing in mind. On the one hand, we may refer to a history of imperial rule, which describes a practice and rationality that exterminates aboriginal populations; 9 at the same time, as Mehta argues, there is also a liberal notion of empire which is predicated on various assumptions of "tutelage" and kinship. It is this notion of colonialism that views the native population as the target of interventions to re-arrange cultures and identities towards an image of progress and civilisation. It is this latter teleological sensibility that I am concerned with here in relation to a view of law, more particularly in the attendant legal subject-citizen that arises from the political community founded on these social evolutionist liberal principles. In it resides a triumphalist and self-vindicating legal narrative that absorbs its paradoxes, contestations and violence over time. But, as Mehta notes, the work of criticism is to render visible and think through the implications of these paradoxes and tensions:

The facts of political exclusion - of slaves, of women, and of those without sufficient property to exercise either suffrage or real political power - over the past three and a half centuries must be allowed to embarrass the universalistic claims of liberalism. (Mehta 1999, 76) ${ }^{10}$

For Hobbes, as we know, the state of nature is one in which "men" find themselves if not in war, then in the permanent disposition towards war, where the condition of "man" is said to be "solitary, nasty, and brutish" ([1651] 1985, 9). This violence lacks a legal-moral character, since it is without a normative boundary for the subject to be within or to transgress. It is only with the arrival of an exterior and common law that such a character can be given to both the disposition and more particularly, the action, which now has a line over which to traverse, with consequences: "till they know not a law that forbids them: which till Lawes be made they cannot know; nor can any Law be made, till they have agreed upon the Person that shall make it" (187).11

The redeeming feature of human beings, in this schematic metaphysics of the shift from the "state of nature" to political society, is the endowment of "reason." Through the capacity to reason, two imminent ideas are revealed: the disposition towards a condition of "liberty" is considered a natural right; secondly, the exercise of that liberty, understood in its negative sense as the "absence of external impediments" undermines, through the insecurity that arises out of the equal right to wage private war, the first right (189). In other words, it negates the freedom to be free. This Right of Nature (Jus Naturale) brings into being therefore a general state of insecurity, based on the exercise of private reason, leading to the condition of man as "nasty, short and brutish." And it is from the private reason of liberty that law as obligation emerges. Law is therefore at odds with Natural rights, argued Hobbes, "like obligation is at odds with Liberty" (189). The distinction between Jus (Right) and Law (Obligation) is the basis of a form of sociality through which the "individual" can protect and enjoy the rights that are put into question in the absence of a "common law."12 As Hobbes describes it:

That a man be willing when are so too, as farre forth, as for Peace, and defence himselfe he shall think it necessary to lay down his right to all things, and be contented 
with as much liberty against other men, as he would allow only against himself. ([1651] 1985, 188-190)

In this reworking of the Biblical injunction "doing unto others," it is the self that is placed at the centre of the "motivation" for the transfer of absolute rights to the sovereign. Reasonable men would thus see that they had to give up some of their rights to everything and to protect themselves in order to live in Peace, not War. However, because men are governed by the "Passions," they would revert to their natural ways if they saw advantage in a situation. Hence the need not only to agree by word, but also to agree by action to transfer their natural rights to an Authority, for: "Covenants, without the Sword, are but Words, and no strength to secure man at all" (Hobbes [1651] 1985, 192, 201-202). This "covenant," in the form of the "social contract," is therefore to be protected by the threat of force, and mediates the relationship between the Authority, "the commonwealth" or state, and the "citizen" as the embodiment of rights and obligation and allows for the distinction to be made between that which is legal and that which is illegal: "whatever I lawfully Covenant, I cannot lawfully break" (198). The making of a covenant, the agreement to be governed in actions by a common Law therefore creates "obligations," and creates "injustice" as Sin Jure (191):

And in this law of Nature, consisteth the Fountain and Originall of JUSTICE. For where no Covenant has preceded, there hath no Right been transferred, and every man has right to everything; and consequently no action can be Unjust. But when a Cove nant is made, to break it is Unjust: And the definition of INJUSTICE, is no other than the not Performance of the Covenant. And whatsoever is not Unjust, is Just.

Justice and injustice are therefore premised on the upholding of the laws of the covenant. More so, for Hobbes, as I have noted above, the basis of these laws of the covenant, if they are to not be mere "words," must have behind them the capacity of force:

Therefore, before the names of Just, and Unjust can have place, there must be some coercive Power, to compel men equally to the performance of their Covenants, by the terror of some punishment, greater benefit they expect by the breach of their covenant. (ibid.)

The very naming of justice itself is therefore, in this genealogy, premised on the existence of the creation of security through the ordering of violence, not as arbitrary, private and random, but as public, regularised and knowable, through law, and therefore, administered as the upholding of rights or the righting of wrongs, under the newly inaugurated name of "justice."

Later, Locke, in the Two Treatises of Government ([1689] 1993), was to take the social contract theory as the basis of government further. Drawing on a more optimistic view of the state of nature, where violence was present in potential rather than manifestation and in disagreement with Hobbes's (and Robert Filmer's) centralised commonwealth despot of the Leviathan, Locke argued that accepting a centralised allpowerful sovereign "is to think that men are so foolish that they care to avoid what 
mischiefs may be done them by polecats or foxes, but are content, nay think it safety, to be devoured by lions" (53). As an alternative, Locke proposed a separation of powers within the commonwealth, with the Legislative and Executive functions bound by the rules upheld by the Judiciary. What Locke shared with Hobbes was the belief that the commonwealth, or government, was created not to protect its own interests but through an imminent revelation of reasoned access to knowledge, which would allow for the exercise of pre-political natural rights - in his case, the right to life, to liberty and to property - through a common law. These rights to life, liberty and property are God-given rights and are knowable and discernable to those with the capacity for reflection and reason. ${ }^{13}$ Again, like Hobbes, it is reason - and therefore the assumption of the possession of the capacity to reason - that reveals the existence of natural rights, not dependent on time and space, but "writ in the hearts of all mankind" (86). ${ }^{14}$ As he was to argue, drawing on Christianity, "God, who hath given the world to men in common, hath also given him reason to make use of it to the best advantage of life and convenience" (127). There is an important caveat of course to note here: not all possess the capacity to reason. He qualified the statement, by remarking that whilst God had indeed given the "world to men in common," this should not be taken to mean he meant for it to remain in common or uncultivated: "He gave it to the use of the industrious and rational, and labour was to be his title to it” (131).

The conception of an independent judiciary, it is argued, arises from this conception of law, which creates a distinction between law and the realm of politics. Natural law, in its secularised version, makes claim to a set of rights against which the realm of the political give form, are judged by, and have to conform to. These are constituted as "fundamental" rights over which judicial interpretation exercises sovereignty. Whilst evident in Greece and in the uncodified rules of the Roman Republic, in its modern form Locke and more particularly, the French philosopher Montesquieu ([1777] 1989) provides the intellectual authority for the idea of a separation of powers. ${ }^{15}$

I am not casting aspersions on those who did and do use the law to protect legal space for black subjects to exist in white South Africa or to protect migrant refugees. Nor I am casting doubts on the ethics or political imperative to catalogue and document in order to provide legal evidence of human rights violations. What I am drawing attention to are the ways in which subjects are constituted, both as victims and as saviours; and how these come to have political effects that might be quite unforeseen or unintended or contingent, and yet shape the outcomes or the terms on which a wrong comes to be righted. The recourse to human rights during the anti-apartheid struggle, articulated within the legal realm, comes to make it entirely thinkable to constitute apartheid at the TRC as a series of individualised wrongs, committed against individuals by individuals.

Kentridge focused his subsequent comments on the increasingly pernicious effects of racialised segregation and the willingness of the majority of judicial appointees to accept the political nature of the appointments, as well as the legislation they were implementing. Taken as an example of a sentiment, Kentridge's speech also describes a certain legal sensibility and an argument within South African jurisprudence that 
emerged in opposition to the all-encompassing legislative framework of the apartheid state from 1948 onwards and from which the emergence of the recourse to human rights law in South Africa drew its vigour. ${ }^{16}$

In 1972, the Legal Commission of the Study Project on Christianity in Apartheid Society (Spro-Cas) released a report titled Law, Justice and Society (Randall 1972). The report comprised a series of individually authored papers, described by the Commission's Secretary, John Dugard, as an attempt to "create an awareness on the part of the legal profession and the lay public of the incompatibility of apartheid's legal order with the ethical principles upon which Western legal systems are based" (Randall 1972, 2). John Dugard had become one of the most eminent South African scholars and advocates of human rights with a growing international prominence. ${ }^{17}$ Spro-Cas itself was a project that had its origins not only in the legal fraternity, and it was funded by the South African Council of Churches and the Christian Institute of South Africa.

The Spro-Cas Legal Commission's report converges on two universalising ethical domains: a Christian ethic, premised on the normative question of whether apartheid was consistent with being a Christian, and a secular legal ethic, premised on whether apartheid was consistent with the progressivist ideals of Western law. ${ }^{18}$ The opening paragraph of the report gives a genealogy of South African common law as derivative of a "blend of principles." These derive from Roman-Dutch law, as well as principles of English common law. But it also notes that this law is:

not merely a product of the legal genius of Rome and the Netherlands and the experience of English law; it is also the product of Judeo-Christian philosophy, the legal manifestation of Western Christian civilization. The South African common law reflects the ethical values of Western society in its detailed body of laws and customs, promoting, through the instrument of the law, respect for the individual - his life, liberty, family and basic freedoms - and equality before the law. (3)

In this narrative of the location of the historical and cultural filiality of law, we are beginning to see the image of a certain conception of the role of law, its genealogy and its legal subject. In other words, it is a narrative of where the law that we value comes from, how it evolves, and where it places those who remain faithful to it, both ethically, but also within a geo-spatial imaginary. Its unstated premise is that this is a version of law that is in Africa but not of Africa. This is described as the "heritage" that had to be defended (3). At its normative core is a rights-bearing individual, a familiar figure embodied in liberalism's political subject. The Legal Commission report is concerned principally therefore with how the policies of the government's legislation and its practices impacted on the universal enjoyment of these "Judeo-Christian" values by individual citizens. Do all citizens enjoy their individual rights, are they free and equal, and do they have unfettered access to the law? This narrative of law embeds itself firmly therefore in a "Western" genealogy and at the same time ascribes to this particularity a universal purchase.

There is an important difference in the critique of apartheid that emerges at this point. The UN declaration on apartheid as a crime against humanity highlighted four 
aspects: denationalisation, political participation, self-determination and force. In contrast to this view, the South African human rights-derived critique of apartheid evolves to take a different view on the wrongs of apartheid. In its view "racial discrimination" rather than self-determination and the right to sovereignty are the key feature. It comes to focus on force - its victims and its perpetrators - as the most visible wrong of apartheid. The idea of a "white South Africa," surrounded by "homelands" for the various "tribes," would require a violence of immense scale - the forced removals and relocations, the control and regulation of movement, the policing of boundaries, all of which, if the regime was to be a bastion of "Western civilisation," would be done through law. A series of laws were placed on the statute books, which had a threefold aim: to create a nationally applied and imposed singular order of law which legally classified the population by race and ethnicity; to create the legal framework for two modes of political authority, one for natives and one for race groups; and to create the legal framework for the ethically and racially ordered provision of social life and social welfare. At the interstices of these bifurcated zones of belonging and exclusion were those who make the case for the universal, from various foundational grounds - religious, moral, ideological, political, ethical and legal. It was for this latter group in particular, that a recourse to human rights would appeal, since it could make visible, and bring into question the developmental claims of the Nationalist Party-led government after 1948 by demonstrating the systematic and widespread nature of the violations the implementation of these policies had on the individual as a subject of suffering, in other words, as a victim. The tension here for human rights lawyers is that modern legal rights rest on the metaphysically derived notion of a set of rights which are immanent and pre-political. These are translated in thought, through concepts and mythologies (and secularised) as the foundations of modern positive law. There is the law that is (sacred, divine, God-given) and there is the law that emerges from the labour of thought as the product of reason, the law that is not "natural" but human - positive law. When human rights lawyers endeavour to critique the legality of the apartheid state and its laws, how would they pit one form of positive law against another?

The electoral victory of the Nationalist Party in 1948 brought to a colonial and segregationist history a refinement of the idea of what Partha Chatterjee (2006) has called "the rule of colonial difference" - the permanence and radical otherness of the native which required a different path to self-improvement and development, via the structures of tradition and custom. It was in this context that the rise to hegemony in the mediation of pain and suffering of human rights law and the figure of the human rights lawyer must be located. In its institutional forms, a related mediating institution between the (white) lawyer - the "bridge builder" - and the (black) subject of apartheid is the "Advice Office" or the Advice Bureau. An archetypical example of this is the formation and history of the Black Sash, a non-governmental organisation. ${ }^{19}$ In this realm, "racial discrimination" became the dominant marker of what apartheid was about. Race was seen in this rationality as the grounds upon which individuals were denied the universal by their place in the epidemiological taxonomy and which condemned them to their particularity. They were thus excluded from liberalisms' universal capaciousness. To correct this exclusion, the modern political subject could make civil claims through law. More precisely, claims could be made through the 
mediating figures of law - those considered citizens with rights - on behalf of those considered non-legal - the subject races of apartheid. This mode of critique establishes an idiom and a style of evidentiary practice that requires not only a corporeal subject of suffering, but also an empirically verifiable corporeal agent of pain, a perpetrator, which a skillful lawyer could bring into the same orbit with the victim by linking the two in order to demonstrate culpability. It is this genealogy of speaking about pain and suffering that comes to hegemony through its capacity to speak, as racial citizens, in a language and in a way that frames the wrong of apartheid as racial discrimination and which finds a global traction in and through a universalised liberal subject as its index.

By the late 1970s, the major political challenge facing the apartheid state, following the 1976 uprisings, is that apartheid's grand plan to denationalise the native subject was brought into crisis. State reform measures in the period thereafter seek to address this challenge through a reconfigured conception of local government designed to co-opt a layer of black urban leadership in townships. Importantly, and with significant consequences for the counter-insurgent aims underpinning the hopes of the state, the regulation of black life under this reformed local government system could not distinguish and demarcate the residential life of black South Africans along ethnic lines within South Africa, as it did in the homelands. Urban African townships were a heterogeneous mix (this is not to say that socially there were not ethnicised spatial enclaves within townships decided on by Africans themselves). The state had to contend now with a spatial mode of control in its regulation of life in African townships. It had to govern native life through the corporatised identity of blackness, rather than its preferred taxonomic classification of Africans as multiple ethnicities as it had under the Native Authorities Act and other customary law stipulations. This forced it to shift slightly from its imaginary of the bifurcated vision of apartheid, divided between racial citizens and ethnic subjects. It had also therefore to find an alternative mode of regulation and control, of law and order, if it could not hope to govern urban African life through the "decentralised despotism" of the chief. It was conceding the legitimate right of Africans to be resident in "white South Africa," rather than enforcing their status as anxious temporary sojourners, and therefore permanent potential criminals for merely being present in an urban setting. The anxious urban native subject ultimately, and politically, makes a claim not to be constituted as a victim whose pain and suffering is mediated by the citizen who can access legal claims. In other words, for the human rights lawyer, the urban native subject is the refugee, the person who does not have the right to have rights. For the anxious urban black subject, the political demand is different - it is the demand to make residency the grounds for citizenship. This is the paradigmatic politics of the township: to transform precariousness into permanence, insecurity into belonging, refugee into citizen.

\section{Conclusion}

Forced removals, and the creation of homelands that are the spaces for the existence of apartheid subjects, rather than its citizens, share with the refugee camp then its key feature: the camp, like the homeland Bantustan, and the township where those forcibly evicted are relocated, is a site of displacement, and the location of pain and suffering. It is worth noting that the memorialisation of migrant labour exists in post-apartheid 
South Africa through "community" initiatives, like the Lwandle Migrant Labour Museum on the outskirts of Cape Town, ${ }^{20}$ or as part of an unofficial memorialisation. This initiative seeks to mark the displacement and narrate the pain and suffering that arises from the desire to have the native be a subject that migrates into the urban area, but does not belong there. The condition of the black subject under apartheid might be described as the condition of the refugee. And like the refugee in the camp, the anxious urban native South African increasingly comes to be constituted within a certain mode of critique that arises against this condition, as a victim, and a target that is the object of care.

Like the refugee in the camp around which an entire discourse of pain and suffering emerges and around which humanitarian technologies and humanitarian beings act, the refugee requires its advocates. These often take the form of international NGOs who mediate the pain and suffering of the refugee through a discourse of care which universalises the condition of the victim across time and space as an abstracted human rights violation. So too did apartheid's ethnic subjects come to find themselves increasingly being mediated as victims of pain and suffering by their own advocates quite literally advocates of law. The lawyers and paralegal community that came into being to draw attention to, and fight the case of, the victims of apartheid's most brutal aspects - its will to denationalise the majority and to reorder belonging and territory. Those who were racially classified had access to civil law and could make a case on behalf of those who were ethnically subjected to the violence and insecurity of a precarious urban existence. Both the discourse of care that emerges around the refugee in the camp and the discourse of law that emerges around the black subject proclaim themselves non-political. Humanitarianism asserts care in ethical and biomedical terms. It constitutes the victim in universal terms abstracted from history, identity, and politics. Law narrates its autobiography in a similar fashion. Like care, law is something to be administered. It holds on to a self-representation that divests law of a politics. ${ }^{21}$

Another way of looking at the violence that characterised South Africa's townships under late apartheid would be to see it as the claiming of a collective right: the right to belong as a citizen, based on residency - to undo a colonial braiding of space and place and the right to belong. These were the political claims made by formations within townships, which demanded self-determination and self-representation. From this vantage point, apartheid was its will to denationalise rather than its exceptional violence. In other words, the question of who could be a citizen. The category of native and refugee speaks then centrally to a postcolonial African dilemma. The solution to the desire to denationalise the indigenous in many African countries was to see justice as the privileging of those considered indigenous as the rights-bearing postcolonial political citizen. The legacy of colonial rule was to politicise indigeneity (Mamdani 1996), making it the ground of citizenship or for being considered a foreigner, often a refugee. Rather than a temporary exception, the refugee camp then becomes normalised. The refugee camp might then be the paradigmatic metaphor for one of our postcolonial dilemmas: the care of those who come from elsewhere, but who never can belong as long as descent rather than locality is the yardstick for rights and citizenship. A question, and it is, above all, a political question - where "citizen" is to name a litigious 
condition, following Rancière, then remains: when, and under what conditions, might the refugee be freed from the camp and transformed from the victim, the person who comes from elsewhere, into a citizen? It is a political question insofar as it prescribes the answer to the question: who can be the political subject?

\section{Acknowledgements}

Versions of this paper were presented to the 13th General Assembly of CODESRIA in Rabat, Morocco, the Social Factory colloquium in Cairo, Egypt, and the Makerere Institute for Social Research seminar series in Kampala, Uganda. I wish to thank participants in those forums, as well as the anonymous reviewers of Social Dynamics, for helpful comments. 


\section{Notes}

1. http://www.thefreedictionary.com/anxious.

2. This was a research project of the Democracy and Governance Programme of the Human Sciences Research Council of South Africa (2008). The report was not without its critics, and was the subject of a critical exchange between this author and the South African anthropologist John Sharp; cf. Sharp (2008) and Pillay (2008).

3. An account of this controversy can be found in the report of the South African Human Rights Commission (2000).

4. "Foreigners Displaced by Violence in South Africa Move into Temporary Camps." The Canadian Press, accessed June 30, 2008.

http://canadianpress.google.com/article/ALe-qM5ibeZeGJbRIF2sQiMsqquz3WRICMw; “Camp Conditions Alarm SACC.” News24, accessed June 30, 2008. http://www.news24.com/News24/South_Africa/Xenophobia/o,2- 72382_2346122,oo.html. "Reintegration the Priority - Government." Independent Online, June 4, 2008. http://www.iol.co.za/index.php?set_id=1\&click_ id=13\&art_id=nw20080604125107561C769068; "Go Home or Go Back: Home Affairs." The Times (SA), accessed June 30, 2008.

http://www.thetimes.co.za/SpecialReports/Xenophobia/Article.aspx?id=780888; "No 'Forced Reintegration' for Immigrants." The Times (SA), accessed June 30, 2008. http://www.thetimes.co.za/SpecialReports/Xenophobia/Article. aspx?id=781999; “Govt: Victims of Xenophobia won’t be Deported.” Mail \& Guardian, June 20, 2008. http://www.mg.co.za/article/2008-06-20-govt-victims-of-xenophobia-wont-bedeported; "Cape Town Wants to Evict Refugees." The Times, accessed May 11, 2009. http://www.thetimes.co.za/News/Article.aspx?id=996699.

5. The genealogy of this argument in African colonial governmentality can be found in the Hamitic hypothesis. Cf. Mamdani (2002b), and also Pillay (2004).

6. Section 5(1) notes that "Every person whose name is included in the register shall be classified by the Director as a white person, a coloured person or a native, as the case may be, and every coloured person and every native whose name is so included shall be classified by the Director according to the ethnic or other group to which he belongs." Section 7(1) notes that "There shall, in respect of every person whose name is included in the register, other than native, be included in the register the following particulars and no other particulars [...]," and it then lists a series of categories including age, sex, date of birth and so on. Section $7(2)$ in a separate subsection sets out the provisions for those defined as "natives": "There shall be in respect of every native whose name is included in the register, be included the following particulars [...]" and it then sets out a similar list, with a few additions: it adds "his citizenship, or nationality, the ethnic or other group and the tribe to which he belongs" (emphasis added) (Brookes 1968, 19-20).

7. Sidney Kentridge became a senior counsel in 1965 in South Africa, and was a defence lawyer in some of the most significant political trials, including the Treason Trial (1958- 1961); he later represented the family of the late Black Conscious leader, Steven Bantu Biko, at the inquest into his death in police custody in 1977. Thereafter, Kentridge practised law as member of the English Bar, and was appointed Queen's Counsel in 1984. He served as a judge in Botswana and an Acting Justice in the Constitutional Court of post-apartheid South Africa. This biographical information taken from website of the Presidency of the Republic of South Africa on the occasion 
of a national order of merit to Kentridge for his role as an anti-apartheid lawyer: http://www.thepresidency.gov.za/ orders_list.asp?show=395, accessed May 1, 2010.

8. Thomas Hobbes and John Locke, as well as Jean-Jacques Rousseau, are taken to be among the most important Enlightenment theorists of a form of government based on the idea of natural rights, drawing on the earlier writings of Hugo Grotius (15831645) and Samuel von Pufendorf (1632-1694). Noting a distinction between different national conceptions of the natural rights concept, Waswo (1996), in his account of the American genealogy of the concept, as distinct from the British, argues that the early Puritans accepted that it was "natural" that "men" would seek liberty, but they also saw that it contained a threat. Writing in 1630, John Winthrop was to make a distinction between two forms of liberty. The first he described as natural and the second as "civic" or "federal." "The First," he argued, "is common to man with beast and other creatures"; and he went on, the "exercise of this liberty makes men grow more and more evil and in time to be worse than brute beasts: omnes sumus licentia detoriores. The other kind of liberty I call civil or federal; it may also be moral, in reference to the covenant between God and man, in the moral law [...] This liberty is the proper end and object of authority and cannot subsist without it" (743-744). See also Hussain (2003).

9. An example of this invocation of Empire can be found in Lindqvuist (1992).

10. The paradoxes between universal claims have been articulated in various forms. In the moment of imperialism, which exterminates the colonial subject, there are the famous debates on the right to imperium and dominum (Grovogui 1996, 17-25). For the latter paradoxes, see also Mommsen and de Moor (1992) and Stoler (1989a, 1989b).

11. To clarify, when Hobbes uses "law" in lower case he refers to the concept of law in general, but when he speaks of "Lawes," he is describing the particular transcendental law which monopolises authority over violence in the contractual justification for obligation to a sovereign political authority.

12. The Enlightenment formulation of a natural law tradition, out of which this conception of justice arises, draws on a number of historical precursors. In the genealogy of the concept in the West, it is to Aristotle that we most often turn, although there is some dispute about this; see Charles H. McIlwain (1932, 114-115). Particularly, it is to Aristotle's distinction between distributive and corrective justice, the latter arising from a pre-given sense of right, which lends itself to a historically transcendent conception of law and right in the Nicomachean Ethics and Politics and Rhetoric (see Leo Strauss's Natural Right and History [1987]). Plato's conception of natural law entered the mainstream of Western legal thought through the Aristotelian commentary on the Republic by the Andalusian Muslim polymath Ibn Rushd (Averroes), as well as through the writings of Thomas Aquinas (Henry 1993, 39).

13. In the genealogy of natural law, the Enlightenment interpretation is distinguished from the Medieval and Christian conception of jus gentium by the status of natural law in relation to obligation and compliance, which derives from a general acceptance, rather than a rule or force. This is taken up in modern law as "the general principles of law recognized by civilized nations" (see for example the Statute of the International Court of Justice, art. 38, from the Latin principle of ius cogena erga omnes, translated as "law that is compelling in relation to everyone," or "higher law" or "fundamental human rights," cf. Hart [1994]). Aquinas argued that whilst the positive legal system

\section{https://repository.uwc.ac.za/}


"derived from natural law," these only carry legal force as part of a posited system: ex sola lege humana vigorem habent: ST I-II, q. 95.a3; see Finnis (1980), Fuller (1969).

14. According to Carlyle $(1927,83)$, this finds its way into Christian doctrine on natural law through Cicero.

15. This point is elaborated on in Althusser (1972), Balandier (1970, 3) and Shklar (1989).

16. It was also a debate presented as a case of the particularity of Afrikaner nationalism's understanding of law as moral communal values, contrasted with the more universalist and "progressive" orientation of liberal English-speaking white South Africans and the legal tradition they sought to protect; see Lewin (1963).

17. Besides his copious writing on apartheid and human rights law, Dugard has served as an ad hoc Judge on the International Court of Justice and as a Special Rapporteur for both the former United Nations Commission on Human Rights and the International Law Commission. More recently he has been, in the latter capacity, investigating human rights violations, as well as the colonial and apartheid features of the Israeli occupation of the Palestinian territories of the West Bank, and Gaza in particular. For his views on the apartheid features of Israeli occupation, a transcript of a lecture is accessible at http://www.thejerusalemfund.org/ht/d/ContentDetails/i/5240 (accessed July 3, 2010).

18. Whilst some might suggest an incompatibility between this secular and religious convergence, Alain Supiot (2007) has argued convincingly that these are historically entwined domains of a modern rationality.

19. BC 668 (B1.1), Manuscripts and Archives Department, University of Cape Town Libraries.

20. http://www.lwandle.com/.

21. As I have discussed above, that apartheid was legal, liberal critics argued, was an aberration of law rather than a calling into question of the Western legal tradition itself.

\section{Notes on contributor}

Suren Pillay is Associate Professor in the Centre for Humanities Research at the University of the Western Cape. His current research focuses on the contemporary legacies of colonial rule in law, governmentality, political violence and knowledge production. 


\section{References}

Adam, H. 1988. "Engineering Compliance. The Management of Dissent in South Africa." In Law and Justice in South Africa, edited by J. Hund, 172-192. Cape Town: Center for Intergroup Studies, Institute for Public Interest Law and Research.

Althusser, L. 1972. Politics and History: Montesquieu, Rousseau, Marx. London: New Left Books.

Arendt, H. 1973. Origins of Totalitarianism. New York: Harcourt Shocken. Balandier, G. 1970. Political Anthropology. New York: Random House.

Brookes, E. H. 1968. Apartheid: A Documentary Study of Modern South Africa. New York: Routledge \& Kegan Paul.

Carlyle, A. J. 1927. A History of Medieval Political Theory in the West, vol. 1. New York: Barnes \& Noble.

Chatterjee, P. 2006. The Politics of the Governed: Reflections on Popular Politics in Most of the World. New York: Columbia University Press.

Fanon, F. 1963. The Wretched of the Earth. New York: Grove Press.

Finnis, J. 1980. Natural Law and Natural Rights. Oxford: Clarendon Press.

Friederichs, D. O. 1990. "Law in South Africa and the Legitimacy Crisis." International Journal of Comparative and Applied Criminal Justice 14 (2): 188199.

Fuller, L. 1969. The Morality of Law. New Haven, CT: Yale University Press.

Grovogui, S. 1996. Sovereigns, Quasi Sovereigns and Africans: Race and SelfDetermination in International Law. Minneapolis, MN: University of Minnesota Press.

Hart, H. L. A. 1994. The Concept of Law. 2nd edition Oxford: Clarendon Press.

Henry, C. 1993. History of Islamic Philosophy. Translated by L. Sherrard and P. Sherrard. London: Kegan Paul.

Hobbes, T. [1651] 1985. Leviathan. Harmondsworth: Penguin.

Human Sciences Research Council of South Africa. 2008. Citizenship, Violence and Xenophobia in South Africa: Perceptions from South African Communities. Democracy and Governance Research Programme. Pretoria: HSRC Press.

Hussain, N. 2003. The Jurisprudence of Emergency: Colonialism and the Rule of Law. Ann Arbor: University of Michigan Press.

Kentridge, S. 1987. Law and Lawyers in a Changing Society: The First Ernie Wentzel Memorial Lecture. Johannesburg: Centre for Applied Legal Studies.

Lewin, J. 1963. Politics and Law in South Africa. London: Merlin Press.

Lindqvuist, S. 1992. Exterminate the Brutes: One Man's Odyssey into the Heart of Darkness and the Origins of European Genocide. New York: The New Press.

Locke, J. [1689] 1993. The Two Treatises of Government. London: Everyman.

Mamdani, M. 1996. Citizen and Subject: Contemporary Africa and the Legacy of Late Colonialism. Princeton, NJ: Princeton University Press.

Mamdani, M. 2002a. "Making Sense of Political Violence in Africa." Identity, Culture and Politics 2 (3): 1-24.

Mamdani, M. 2002b. When Victims Become Killers: Colonialism, Nativism and Genocide. Princeton, NJ: Princeton University Press.

Mamdani, M. 2002c. "Amnesty or Impunity? A Preliminary Critique of the TRC." Diacritics 32 (3-4): 33-59.

Mbeki, G. [1964] 1984. The Peasants Revolt. Cape Town: Mayibuye Books. 
McIlwain, C. H. 1932. The Growth of Political Thought in the West: From the Greeks to the End of the Middle Ages. New York: Macmillan.

Mehta, U. S. 1999. Liberalism and Empire: A Study in Nineteenth Century British Liberal Thought. Chicago, IL: University of Chicago Press.

Mommsen, W. J., and J. A. de Moor, eds. 1992. European Expansion and Law: The Encounter of European and Indigenous Law in 19th and 2oth Century Africa and Asia. Oxford: Berg.

Montesquieu, C. [1777] 1989. Spirit of the Laws, edited by A. M. Cohler, B. C. Miller, and H. S. Stone. Cambridge Texts in the History of Political Thought. Cambridge: Cambridge University Press.

Moyn, S. 2010. The Last Utopia. New York: Columbia University Press.

Pillay, S. 2004. "Where Do You Belong? Natives, Foreigners and Apartheid South Africa." African Identities 2 (2): 215-232.

Pillay, S. 2008. "Fortress SA? A Response to John Sharp." Anthropology Today 24 (4): 22. Rancière, J. 2004. "Who is the Subject of the Rights of Man?" The South Atlantic Quarterly 103 (2-3): 297-310.

Randall, P., ed. 1972. Law, Justice and Society: Report of the Legal Commission of the Study Project on Christianity in Apartheid Society. Johannesburg: Spro-Cas Publication no. 9.

Sharp, J. 2008. "Fortress SA, Xenophobic Violence in South Africa." Anthropology Today 24 (4): 1-3.

Shklar, J. 1989. Montesquieu. Oxford: Oxford University Press.

South African Human Rights Commission. 2000. Lindela at the Crossroads for Detention and Repatriation. Pretoria: HRC.

Steytler, N. C. 1987. "Criminal Justice and the Apartheid State." In Race and the Law in South Africa, edited by A. J. Rycroft, 66-98. Cape Town: Juta.

Sto er, A. L. 1989a. "Making Empire Respectable: The Politics of Race and Sexual Morality in 20th c. Colonial Cultures." American Ethnologist 16 (4): 634-660.

Stoler, A. L. 1989b. "Rethinking Colonial Categories: European Communities and the Boundaries of Rule." Comparative Studies in Society and History 31 (1): 134161.

Strauss, L. 1987. Natural Right and History. Chicago, IL: University of Chicago Press. Supiot, A. 2007. Homo Juridicus: On the Anthropological Function of the Law. New York: Verso.

Wacks, R. 1984. "Judges and Injustice." South African Law Journal 101: 266-285.

Wa wo, R. 1996. "The Formation of Natural Law to Justify Colonialism 1539-1689." New Literary History 27 (4): 743-759. 